Maurer School of Law: Indiana University

Digital Repository @ Maurer Law

1998

\title{
Rhetoric, Pragmatism and the Interdisciplinary Turn in Legal Criticism - A Study of Altruistic Judicial Argument
}

Gene R. Shreve

Indiana University Maurer School of Law, shreve@indiana.edu

Follow this and additional works at: https://www.repository.law.indiana.edu/facpub

Part of the Jurisprudence Commons, and the Legal History Commons

\section{Recommended Citation}

Shreve, Gene R., "Rhetoric, Pragmatism and the Interdisciplinary Turn in Legal Criticism -- A Study of Altruistic Judicial Argument" (1998). Articles by Maurer Faculty. 561.

https://www.repository.law.indiana.edu/facpub/561

This Article is brought to you for free and open access by the Faculty Scholarship at Digital Repository @ Maurer Law. It has been accepted for inclusion in Articles by Maurer Faculty by an authorized administrator of Digital Repository @ Maurer Law. For more information, please contactrvaughan@indiana.edu. 
GENE R. SHREVE

\section{Rhetoric, Pragmatism and the Interdisciplinary Turn in Legal Criticism-A Study of Altruistic Judicial Argument}

\section{The Setting}

It is a pleasure to be the United States Reporter for a one-word topic as spacious and beguiling as "arguability." Since most academic writing in this country has become argument, the topic might be read locally to authorize a paper on any legal subject. The longer French version of the topic, however, seems to impose some discipline. With help, I translate it as: "What criteria would you use to determine the possibility of presenting a given legal argument?" 1 A literal-minded (and no doubt acceptable) approach to this topic might discuss whether or why certain arguments are effective before judges of the writer's country.

A response that narrow, however, does not seem the only possibility. Even the French version grants considerable license, particularly when we recall that our topic is actually a subdivision of the second topic set for the Fifteenth Congress: "General Legal Theory and Legal Philosophy." Scholars who persist in the searches traditional to legal philosophy (jurisprudence) ${ }^{2}$, for overarching values or for broad systemic order in law, would probably see our topic as an open door. These metatheorists would read "a given legal argument" as any assertion of legal justification-no matter how complex or theoretical-made in court, in the community, or merely in one's mind.

Gene R. Shreve is Richard S. Melvin Professor of Law, Indiana University. The author wishes to thank Fred Aman, Dan Conkle, Perry Hodges, Ken Dau-Schmidt, Steve Johnson, Bruce Markell, Marshall Leaffer, Lauren Robel, Emily Van Tassel, and Elisabeth Zoller for their helpful comments on this Essay.

1. "Quels criteres pour determiner la possibilite de plaider un argument juridique donne?"

2. This Report usually employs "jurisprudence" in place of "philosophy of law"a practice that is permissible so long as we give to jurisprudence its broadest and most common meaning: "the study not of the actual laws of particular legal systems, but of the general concepts and principles that underlie a legal system or that are common to all such systems." Soper, "Jurisprudence," in the Cambridge Dictionary of Philosophy 394 (1995). 
Neither the narrow nor the expansive reading of our topic is free of difficulty. They actually pose something of a dilemma.

In the United States, it would probably be a fatal contradiction to treat the topic narrowly yet call the result a paper on jurisprudence. The presumptions here are that any useful writing on jurisprudence must be a work of high intellectual purpose, preferably one that displays dazzling theory, erudition extending to nonlegal disciplines, and a flair for confrontation. ${ }^{3}$ So strong are these presumptions that, however helpful an essay using the narrow interpretation of our topic might be in other respects, it would not be an authentic specimen of jurisprudence scholarship in this country.

Yet, while an expansive interpretation of our topic would conform to the outlook here, problems also attend that option. The arena of metatheory is important, perhaps central, to contemporary scholarship in the United States. ${ }^{4}$ The problem is that legal scholarship in the United States is in a process of disintegration. ${ }^{5}$ Edward Rubin recently noted that the "conceptual disarray of legal scholarship has

3. The present shape of jurisprudence scholarship has been summarized this way. Once "legal scholars . . . assumed that jurisprudence can incorporate intellectual disagreements about law into a larger harmonious whole," Minda, "Jurisprudence at Century's End," $43 \mathrm{~J}$. Leg. Ed. 27, 27 (1993). But the subject has since fragmented into "heated debate about the relationship among law, culture, politics, economics and morality." Id. at 28. Large-scale studies of the shift include Neil Duxbury, Patterns of American Jurisprudence (1995); Gary Minda, Postmodern Legal Movements-Law and Jurisprudence at Century's End (1995).

4. Within that arena are metatheorists (who compete with other metatheorists) and the detractors of metatheory. Metatheorists do not always sound like traditionalists, but they traffic on the same level. That is, metatheorists often undertake broadspectrum inquires about personal rights and obligations, and about order and authority in the law. They include Berman, "Toward an Integrative Jurisprudence: Politics, Morality, and History," 76 Calif. L. Rev. 799 (1988); Ronald Dworkin, Taking Rights Seriously (1977); George P. Fletcher, Basic Concepts of Legal Thought (1996); Fried, "Jurisprudential Responses to Legal Realism," 73 Cornell L. Rev. 331 (1988); Richard A. Posner, The Problems of Jurisprudence (1990); John Rawls, A Theory of Justice (1971).

Metatheory's detractors frequently denounce it as futile or worse. Thus, while they are negative in perspective, they extend significantly the discussion of metatheory. Examples may be found in the intersecting realms of critical legal studies, see e.g., Jabbari, "From Criticism to Construction in Modern Critical Legal Theory," 12 Oxford J. of Leg. Studies 507 (1992); Mark Kelman, A Guide to Critical Legal Studies (1987); Solum, "On the Indeterminacy Crisis: Critiquing Critical Dogma," $54 U$. Chi. L. Rev. 462 (1987); post-modern legal theory, see e.g., Feldman, "The Politics of Postmodern Jurisprudence," 95 Mich. L. Rev. 166 (1966); "Postmodernism and Law: A Symposium," 62 U. Colo. L. Rev. 439 (1991); "Symposium-Beyond Critique: Law, Culture, and the Politics of Form," 69 Tex. L. Rev. 1595 (191); and what has been called outsider scholarship, see e.g., Abrahms, "Hearing the Call of Stories," 79 Cal. L. Rev. 971 (1991); Delgado, "Recasting the American Race Problem," 79 Cal. L. Rev. 1389 (1991); Eskridge, "Outsider-Insiders: The Academy of the Closet," 71 Chi.-Kent L. Rev. 977 (1996); Torres, "Critical Race Theory: The Decline of the Universalist Ideal and the Hope of Plural Justice-Some Observations and Questions of Emerging Phenomenon," 75 Minn. L. Rev. 993 (1991).

5. See supra nn. 2 and 3. 
become so familiar to us that we have ceased to regret it."6 Pierre Schlag wrote in a similar vein:

There is nothing quite like the exhilarating experience that comes from reading a provocative new piece of legal thought. Of course, at some point this exhilaration will give way to ennui as the new piece of legal thought unravelsultimately to be classified as yet another possibly clever, perhaps thoughtful, but nonetheless utterly failed contribution. ${ }^{7}$

No one, of course, takes these observations completely to heart. The scholarly efforts of many in the United States (including professors Rubin and Schlag) attest to the belief that jurisprudence is still worth the effort. ${ }^{8}$ It is nonetheless important for us to note the present disarray, because it explains why there is no predictably American response to a topic like "criteria for legal argument," why the topic would occasion here responses differing in subject, form and view.

What approach then should this Essay follow? Should I attempt to catalogue and tie to our topic as many of the divergent developments here as possible? That cannot be done in the space allotted. 9 Should I forgo any attempt to create a general picture of jurisprudence in the United States and follow local practice by reacting to the topic in my own particular way? While that might do for a solely American audience, it would surely limit the informative value of the Essay to participants at the International Congress.

The Essay attempts to escape this dilemma through a kind of compromise. It examines an interesting, but largely unnoticed, phenomenon that the author terms altruistic judicial argument. We will try to consider this phenomenon by using the tools of law as a selfcontained discipline. We will find, however, that the systems and proofs of law do not enable us to complete the closely related tasks set out by this Essay of isolating altruistic argument, defining it, ${ }^{10}$ and

6. Rubin, "The New Legal Process: The Synthesis of Discourse, and the Microanalysis of Institution," 109 Harv. L. Rev. 1343, 1343 (1996). "Any suggestion that some new synthesis-or worse still, paradigm - is imminent would generally be regarded as naive." Id.

7. Schlag, "Normative and Nowhere to Go," 43 Stan. L. Rev. 167 (1990).

8. Professor Rubin urged "new synthesis" for legal scholarship in his article, and Professor Schlag has continued his expansive if quixotic writing on legal theory and culture. E.g., Schlag, "Law and Phrenology," 110 Harv. L. Rev. 877 (1997).

9. Moreover, many comprehensive studies already exist. See Duxbury, supra $\mathbf{n}$. 3; Minda, supra n. 3; Rubin, supra n. 6; Schlag, supra n. 7.

10. That is, to state with some certainty what altruistic argument is and what it is not. This relatively simple concept of definition serves in and outside the law. Cf. Yagisawa, "Definition," appearing in the Cambridge Dictionary of Philosophy 185 (Robert Audi, ed. 1995) (noting "if and only if" mode of "explicit definition"). 
ascribing a theory of value to it. ${ }^{11}$ The Essay therefore enlists from other disciplines the perspectives of rhetoric and pragmatism.

The Essay proceeds as follows. Part II examines the opinion written in an 1827 American conflicts ${ }^{12}$ case, Saul and His Creditors, ${ }^{13}$ which will provide our laboratory for the study of altruistic argument. Part III explores differences between lawyer argument and judicial argument, differentiates self-justifying and altruistic forms of the latter, and suggests how Saul displays the virtues of altruistic argument. Part III deploys logic and common sense in a critique conventional to the discipline of law. Part IV evaluates Saul's altruism differently, through the lenses of rhetoric and pragmatism.

For two reasons, the jurisprudential components of this Essay are not completely assembled until Part IV. First, it is in keeping with the earthbound verities of rhetoric and pragmatism,- the emphasis of both upon application and experience-that I first create for them a practical setting. That is a function of Parts II and III. ${ }^{14}$ Second, the sequence permits important questions about the need and function of interdisciplinary critiques like rhetoric and pragmatism in American jurisprudence. What problems can applications of the two solve that could not be as easily solved through liberal application of common sense?

\section{Saul and His Creditors}

The Louisiana appellate court in Saul faced the question whether a marital couple shared equally property acquired by the

11. That is, at least a general idea of the difference between good and bad attempts at altruistic argument.

12. This legal subject (also called in the United States "conflicts law," "conflict of laws" and "choice of law") is frequently referred to abroad as "private international law." American conflicts law may be defined as follows.

The purpose of conflicts law is to provide an intelligible and principled basis for choosing a substantive rule (perhaps tort or contract) over the competing rule of another place. Rules compete when their application would lead to conflicting results and when the relation of each place to the controversy is such that it is plausible for the rule of either place to govern. Conflicts law must legitimate the choice. It must explain why rejection of one law in favor of another is right.

Shreve, “Conflicts Law-State or Federal?' 68 Ind. L. J. 907, 907 (1993).

13. 5 Mart. (n.s.) 569 (La. 1827).

14. Thus I follow in a small way the strategy used by Thomas Nagel in What Does it All Mean?-A Very Short Introduction to Philosophy (1987). Professor Nagel discussed numerous problems of philosophy in this book without referring to philosophical works or using the terminology of the discipline. He justified his approach this way.

The center of philosophy lies in certain questions which the human mind finds naturally puzzling, and the best way to begin the study of philosophy is to think about them directly. Once you've done that, you are in a better position to appreciate the work of others who have tried to solve the same problems.

Id. at 4. 
husband. The answer sought by the husband's creditors, and the answer available under Virginia law, was no. The answer sought by the children of the deceased wife, and available under Louisiana law, was yes. ${ }^{15}$ The couple had been married in Virginia. They had moved to Louisiana many years before, and it was in Louisiana that the husband acquired the disputed property. The court in Saul resolved the conflict by choosing Louisiana law.

Saul apparently was not a case of first impression. Since prior Louisiana predecent supported the choice of Louisiana law in Saul, the case could have been disposed of with at most a perfunctory opinion. But Judge Potter, writing for the court, refused this shortcut. Issues raised in earlier cases had been reargued in Saul

with so much care by the counsel, and have received such additional light from the laborious investigation bestowed on them, that they come upon our consideration with as much freshness, as if this was the only time our attention had been drawn to them. ${ }^{16}$

Despite the energy and ability displayed by counsel, the court found the issue before it difficult to resolve.

[T] he only question presented for our decision ... grows out of the conflict of laws of different states. Our former experience had taught us, that questions of this kind are the most embarrassing and difficult of decision, that can occupy the attention of those who preside in courts of justice. The argument of this case has shown us, that the vast mass of learning which the research of counsel has furnished, leaves the subject as much enveloped in obscurity and doubt, as it would have appeared to our own understanding, had we

15. Conflicts cases arise in the United States where choice is between domestic law and that of a foreign country; however, the great majority of cases here, like Saul, involve conflicts between the laws of sister states. This is because ours is a federal rather than a unitary system. As I explained elsewhere,

[U]nder our federal system of government, states (rather than the national government) create most of the substantive law governing civil actions in state or lower federal courts. Moreover, while Congress or the Supreme Court has power under the United States Constitution to reduce some or all conflicts law to federal law, little of that power has been invoked. The consequences of this situation. . are that (1) conflicts choices for American courts are usually intra-national (between local state law and that of another state), and (2) choice is largely self-regulated.

Gene R. Shreve, A Conflict-of-laws Anthology 126-27 (1997).

16. 5 Mart. at 570 . Quotations from Saul retain the quirks of punctuation found in the original.

Judge Potter's praise of the work of counsel appears warranted. Samuel Livermore (attorney for the losing side) continued his conflicts research after the case, publishing in 1828 the first American treatise on conflict of laws. See De Nova, "The First American Book on Conflict of Laws," 8 Am. J. of Legal History 136 (1964). 
been called on to decide, without the knowledge of what others had thought and written upon it. ${ }^{17}$

Judge Potter thereafter observed that the conflicts issue in Saul presented

a subject, the most intricate and perplexed of any that has occupied the attention of lawyers and courts: one on which scarcely any two writers are found to entirely agree, and on which, it is rare to find one consistent with himself throughout. We know of no matter in jurisprudence so unsettled, or none that should more teach men distrust for their own opinions, and charity for those of others. ${ }^{18}$

Judge Potter later returned to the point.

When ... so many ... men, of great talents and learning, are thus found to fail in fixing certain principles, we are forced to conclude that they have failed, not from want of ability, but because the matter was not susceptible of being settled on certain principles. ${ }^{19}$

Despite these ruminations, Judge Potter did analyze at great length the sources offered by counsel, including many European authorities. ${ }^{20}$ In the end, the court rejected the creditor's argument that a marital domicile in Virginia implied a marital contract governing property acquired after the couple relocated in Louisiana. This 1827 Louisiana case occupies an important place in our conflicts history. The learned and persuasive opinion by Judge Potter helped to establish resistance in this country to the notion of implied premarital contracts. Such was the influence of Saul that "it shaped the future American marital property conflicts law."21

Yet the significance of Saul's choice-of-law ruling on marital property $^{22}$ will not detain us. The Essay will focus instead on the passages from Saul quoted at length in this Part. They may at first seem curious selections, for the passages do not contribute to the holding in the case. They do not suggest or support (even indirectly) any particular outcome in the case. The passages are not in any normal sense law. These very features, however, are what make the passages useful to our study.

17. Id. at 571-72.

18. Id. at 589 .

19. Id. at 595-96.

20. Id. at 576-608. This prompted Friedrich Juenger to observe that, on the whole, "the opinion in Saul is a model of comparative research." Friedrich K. Juenger, Choice of Law and Multistate Justice 28 (1992).

21. Juenger, "Marital Property and the Conflict of Laws: A Tale of Two Countries," 81 Colum. L. Rev. 1061, 1070 (1981).

22. For more on the continuing importance of this case, see Robert A. Leflar, Luther L. Mcdougal III \& Robert L. Felix, American Conflicts Law 658 and n.6 (4th ed. 1986); Eugene F. Scoles \& Peter Hay, Conflict of Laws 480 and nn. 12-13 (2nd ed. 1992). 


\section{Saul As Altruistic Argument}

\section{A. A First Attempt to Isolate and Define Altruistic Judicial Argument}

We usually associate argument in civil litigation with the work of lawyers rather than of judges. Along with the functions of legal research and factual investigation, argument makes up the essence of the lawyer's role in United States litigation. ${ }^{23}$ For the most part, however, lawyer argument is enslaved by partisan interests. Lawyers purport to argue facts in the name of truth and to argue law for the greater good. In reality, however, our "adversary system" usually compels lawyers to select only those arguments that produce selfserving (client-serving) consequences. ${ }^{24}$

American judges argue too. Their judicial opinions can be understood as written arguments-a higher, more attractive form of argument than that permitted lawyers in our system. Two successive questions shape lawyer argument: What does my client want? What is right about what my client wants? The object of lawyer argument is to get what the client wants. A single question shapes judicial argument by opinion: What is right?25 The essential object of judicial argument is to demonstrate why court (by its judgment or ruling) has

\footnotetext{
23. A basic feature of modern American procedure is the adversary system, in which initiative and responsibility for presentation of the case rests primarily with advocates on behalf of the parties. It is the function of the advocate for the plaintiff to analyze the facts and legal basis if the grievance which will be sued on; to select the appropriate legal concept for presenting the case. . .; to gather before trial the evidence to be presented in support of the case; at trial, to present the evidence by questioning the appropriate witnesses and offering relevant documents; and, at the conclusion of trial, to argue to the trier of fact (judge or jury) that the evidence should lead to a finding for plaintiff. The defense must anticipate the legal contentions and the evidence to be offered by the plaintiff, and present countering evidence at trial.
}

Geoffrey C. Hazard, Jr. \& Michele Taruffo, American Civil Procedure-An Introduction 19-20 (1993). When cases are taken up on appeal, the lawyer's function of argument assumes central importance. See e.g., Karl N. Llewellyn, The Common Law Tradition-Deciding Appeals 30-31 (1960).

24. Thus " $[t]$ he lawyer is expected to represent people who seek his help regardless of his opinion of the justice of their ends. $* * *$ [W] henever he takes a case, he is not considered responsible for his client's purposes." Simon, "The Ideology of Advocacy," 1978 Wisc. L. Rev. 29, 36. Moreover, the lawyer's object "is not. . to provoke thought but rather to provoke closure." Wetlaufer, "Rhetoric and Its Denial in Legal Discourse," $76 \mathrm{Va}$. L. Rev. 1545, 1558 (1990). "[T] he lawyer is always right, and his adversary is always wrong." Id.

25. This imagery reflects the "hands-on" attitude of American judges toward the legal issues in their cases, an attitude that judges from civil code countries in Western Europe, Latin American and elsewhere do not share.

The constitutional theory of the Civil Code reflects the political aspirations of the Enlightenment and the French Revolution. These aspirations included the ideas that legal rules should be exclusively expressed in the statutory pronouncements of the legislature, as the voice of the people. The task of the courts is to ascertain the rules and apply them to specific cases; the task of the advocates is to assist the judge in this ministerial task. 
said yes to the right litigant, how it has fulfilled its duty to dispense justice under law. ${ }^{26}$ But since the court decides prior to writing the opinion, the question shaping judicial argument might better be termed: "Why is the court right?" The opinion is in that sense the court's own legal brief. "It is the justification . . . for the court's deciding the case as they have done." 27

We are likely to find the traceries of this argument in every opinion: (1) a legal rule directing the result in the case, (2) recitation of case facts supporting the court's application of that rule, and (3) argument dismissing contrary rules (if any). We should find these elements of self-justification whenever the court attempts a written opinion, ${ }^{28}$ because justification succeeds only when the court demon-

The theory of the civil law system precludes judicial law making, even in the guise of "interpretation," and it presumes that the truth in court is objectively determinable and not merely a pragmatic choice between conflicting versions.

Hazard and Taruffo, supra n. 23, at 20.

In the United States, separation-of-powers doctrine imposes some restraint on judicial power (particularly as to statutes). Yet, compared to their colleagues in civillaw countries, American judges enjoy enormous political independence to decide what the law is and how it should be applied. See Hart, "American Jurisprudence Through English Eyes: The Nightmare and the Noble Dream," 11 Ga. L. Rev. 969, 970 (1977) (noting "the quite extraordinary role that the courts, above all the United States Supreme Court, play in American government."). A number of features have been offered to explain or exemplify the relative autonomy of American courts. They include their power to nullify legislative enactments (Alexis De Tocqueville, Democracy in America v. 1, pp. 104-07 (Vintage ed. 1954); Frankfurter, "John Marshall and the Judicial Function," 69 Harv. L. Rev. 229 (1955)); acceptance of American judicial decisions as reflections of community values (Grant Gilmore, The Ages of American Law 17 (1977)); Robert E. Keeton, Judging 53-54 (1990)); and the common-law tradition in the United States (G. Edward White, The American Judicial Tradition 37 (1976); Tony Freyer, Harmony \& Dissonance; The Swift and Erie Cases in American Federalism (1981)).

26. A result may be presented as right for substantive reasons (stressing notions like duty, freedom or accountability) or for reasons of procedure (stressing where, when or how particular arguments should be made). The interplay of substance and procedure has been a favorite theme in American law and legal commentary. See e.g., Carrington, "Substance' and 'Procedure' in the Rules Enabling Act," 1989 Duke L. J. 281; Cook, "'Substance' and 'Procedure' in the Conflict of Laws," 42 Yale L. J. 333 (1933); Cooper, "Statutes of Limitation in Minnesota Choice of Law: The Problematic Return of the Substance-Procedure Distinction," 71 Minn. L. Rev. 363 (1986); McClintock, "Distinguishing Substance and Procedure in the Conflict of Laws," 78 U. Pa. L. Rev. 933 (1930).

27. Karl N. Llewellyn, The Bramble Bush-On Our Law and Its Study 37 (1930).

[T] he judge has a number of audiences she must persuade that she is right and that the losing party's lawyer is wrong. The audiences include the appellate courts, the legal community, the losing party (who the judge hopes will leave the courtroom quietly and decide not to appeal the case), and the public at large. At this point, the judge has a series of client-like commitments-to her own decision, to her reputation for getting matters right, to the winning party, and to the reputation of courts and the rule of law.

Wetlaufer, supra n. 24, at 1561 .

28. However, realities of the American judicial process make it impossible either to suggest that written opinions invariably accompany judicial rulings, or to suggest that all of the opinions that one does find have well-developed justifying argument. 
strates that it has found the rule appropriate to resolve the case at hand and others like it. ${ }^{29}$ Once the court has thus argued its defense against the charge of erroneous decision, the opinion may (and often does) stop.

Or the opinion may exhibit additional, nonessential forms of argument. It may, for example, discuss other, theoretical applications of a rule adopted or rejected by the court's decision, or it may offer material that does not directly support the court's decision but does suggest that the court is generally following a desirable course. Argument that is not essential to the court's particular decision but that compliments that decision in ways noted above is frequently termed "dictum," ${ }^{30}$ to separate it from argument that directly explains (supports) the court's decision, termed "holding." This is a time-honored distinction in American law, if not always easy to apply. ${ }^{31}$ But the

To be valid, judgments or interlocutory rulings by American courts need not be accompanied by written opinions. Trial courts may follow their judgments with written opinions, but they are usually obliged to prepare only a truncated document often called "findings of fact and conclusions of law." See e.g., Fed. R. Civ. P. 52(a).

American appellate courts are more apt to accompany their rulings with written opinions, but today these may be so-called unpublished opinions. Rules governing unpublished opinions often restrict their public examination and discussion. See e.g., Reynolds \& Richman, "An Evaluation of Limited Publication in the United States Courts of Appeals," $48 \mathrm{U}$. Chi. L. Rev. 573 (1981). The function of these opinions as argument is therefore in some doubt.

29. The established view here is that a successful judicial opinion must explain why the same result would occur in a category of like cases. Golding, "Principled Decision-Making and the Supreme Court," 63 Colum. L. Rev. 35 (1963); Levi, "An Introduction to Legal Reasoning," 15 U. Chi. L. Rev. 501, 501-02 (1948); Murry, "The Role of Analogy in Legal Reasoning," 29 UCLA L. Rev. 833 (1982); Winston, "On Treating Like Cases Alike," 62 Cal. L. Rev. 1 (1974).

30. Numerous examples appear in Wald, "The Rhetoric of Results and the Results of Rhetoric: Judicial Writings," 62 U. Chi. L. Rev. 1371, 1408-10 (1995).

31. Cf. Henry J. Abraham, The Judicial Process 236 (4th ed. 1980) (holding "constitutes the legal rule to be followed and adhered to; [dictum] is an expression of a belief, viewpoint, or sentiment, which, at least in theory, has no binding effect.").

Judicial dicta has been important in the development of American law. At the same time, its nonessential status in judicial opinions has led to doubts about the authority and even the desirability of dicta. These doubts are due to the nature of American judicial power. Our judiciary's considerable political authority (including the power to invalidate legislation) rests on the notion that a court must be able to determine all the law necessary to decide the case at hand (see Marbury v. Madison, 1 Cranch (5 U.S.) 137 (1803), the discussion of Marbury in this context in Alexander M. Bickel, The Least Dangerous Branch 114-16 (1962); and a discussion of the point generally in James Boyd White, When Words Lose Their Meaning: Constitutions and Reconstitutions of Language, Character, and Community 264 (1984)). The rationale for judicial authority just discussed validates judicial holdings but leaves dicta in limbo.

Thus, even some of those on the United State Supreme Court who made the best use dicta (Chief Justice John Marshall, Justice Oliver Wendell Holmes, and Justice Robert Jackson) were at times wary of the device. Marshall authored Marbury. Holmes wrote: "General propositions do not decide concrete cases." Lochner v. New York, 198 U.S. 45, 76 (1905). Jackson wrote: "It is timely again to remind counsel that words of our opinions are to be read in the light of the facts of the case under discussion. $* * *$ General expressions transposed to other facts are often misleading." Armour \& Co. v. Wantock, 323 U.S. 126, 132 (1944). 
traditional holding \dictum distinction does not really account for a less common form of judicial argument: where a court's interest in justifying its decision is overcome by a broader desire to promote the law and its good effects. This happened in Judge Potter's opinion.

The passages from Saul appearing in Part II make clear that Judge Potter was interested in much more than merely defending the court's ruling, for these passages do not even intimate how the court will rule. But, in a sense important to this Essay, the passages are better for that. We have noted that judicial argument is generally superior to lawyer argument because the concern of the latter is for what is right. In a similar vein, judicial argument in defense of the court's ruling may be on a lower plane from argument unrelated to the question whether the court decided the case correctly.

This is not to suggest that the former is less important. The point is that, as proper and central to the opinion as argument defending the decision may be, it is self-interested, almost compulsory, argument. Judicial dicta in the conventional sense, described earlier, is self-serving as well. ${ }^{32}$ With either, the court is trying to persuade the reader that it acted legitimately. ${ }^{33}$ By comparison, argument indifferent to the result is voluntary and perhaps altruistic. As in Saul, the writer is simply moved to express his or her feelings about law and those who must use it or live under it.

\section{B. Altruistic Argument Illustrated in Saul}

At least three altruistic arguments appear from the portions of Saul identified in Part II. (1) Conflict of laws is a subject meriting careful research and argument by counse ${ }^{34}$ and strenuous analysis and deliberation by courts. ${ }^{35}$ (2) Yet, even with such effort, the subject of conflicts law remains so complicated and confusing that courts must wonder whether any entirely reassuring solutions may be found. ${ }^{36}$ (3) There is thus a need for empathy and solidarity within the community of commentators, courts and counsel who struggle with conflicts problems. ${ }^{37}$

Saul demonstrates the potential of altruistic judicial argument. The court's statements are remarkably visionary, anticipating the crisis today in choice of law. The court's argument is also remarkable

32. The conventional understanding of dictum is that, by alluding to features unilluminated by the actual controversy, it argues for the court's decision in a looser sense. See e.g., Joyce J. George, Judicial Opinion Writing Handbook 245-46 (3rd ed. 1993); Samuel Mermin, Law and the Legal System-An Introduction 289-91 (2nd ed. 1982); Comment, "Dictum Revisited," 2 Stan. L. Rev. 509 (1952).

33. In this sense, which is all-important to the Essay, the traditional holding \dictum distinction provides no useful distinction in fact.

34. Supra n. 16 and accompanying text.

35. Supra n. 20 and accompanying text.

36. Supra nn. 17-19 and accompanying text.

37. Supra n. 18 and accompanying text. 
for being entirely right. Saul justifiably attacks the two most pernicious ideas now afflicting American conflicts law: (1) that the field is too troubled to reward either serious research and careful argument by attorneys or strenuous analysis and deliberation by courts; and (2) that particular choice-of-law rules or approaches are entirely correct, while others are entirely incorrect-viz. difficulties exist in American conflicts law only because certain people are wrong and do not admit it.

It is possible to find numerous expressions of the first idea, that conflicts law is in a troubled, perhaps hopeless state. If the views of commentators, ${ }^{38}$ judges, ${ }^{39}$ and attorneys ${ }^{40}$ are indicative, it remains one of the most confusing and unpopular subjects of American law. But Saul dispels the first idea, as well as the second, that there are clearly right and wrong answers in the conflicts debate, ${ }^{41}$ by insisting that conflicts law deserves to be taken quite seriously even though the subject is innately difficult and may never yield entirely satisfactory answers. Thus, in the high point of the opinion, Judge Potter urges that the legal community (instead of disdaining conflicts law as too

38. Professor William Prosser described conflicts law as "a dismal swamp, filled with quaking quagmires, and inhabited by learned but eccentric professors who theorize about mysterious matters in strange and incomprehensible jargon." "Interstate Publication," 51 Mich. L. Rev. 959, 971 (1953). For a rejection of the field almost as sweeping, see Sterk, "The Marginal Relevance of Choice of Law Theory," $142 U$. Pa. L. Rev. 949 (1994).

Some critics do not completely reject conflicts law would nonetheless abolish its current form and substance as common law, either by absorbing it into various parts of the United States Constitution, e.g., Ely, "Choice of Law and the State's Interest in Protecting Its Own," 23 Wm. \& Mary L. Rev. 173 (1981); Laycock, "Equal Citizens of Equal and Territorial States: The Constitutional Foundations of Choice of Law," 92 Colum. L. Rev. 249 (1992), or into federal statutes, e.g., Gottesman, "Draining the Dismal Swamp: the Case for Federal Choice of Law Statues," 80 Geo. L. J. 1 (1991); Kane, "Drafting Choice of Law Rules for Complex Litigation: Some Preliminary Thoughts," 10 Rev. Litig. 309 (1991).

39. In Erwin v. Thomas, 506 P.2d 494, 495 (1973), the Oregon Supreme Court stated: "It is with some trepidation that a court enters a maze of choice of law in torts cases. No two authorities agree." The court likened use of one of the competing conflicts approaches to "wandering off into the jungle with a compass which everyone but its maker says is defective." Similar views appear in In re Paris Air Crash of Mar. 3, 1974,399 F.Supp. 732, 739 (C.D. Cal. 1975) (conflicts law is a "veritable jungle, which, if the law can be found out, leads not to a 'rule of action' but a reign of chaos."), and in Paul v. National Life, 352 S.E.2d 550, 553 (W.Va. 1986) (conflicts law is "cumbersome and unwieldy [creating] confusion, uncertainty and inconsistency, as well as complication of the judicial task.").

40. "Many lawyers regard modern choice-of-law analysis as a confusing morass." Singer, "A Pragmatic Guide to Conflicts," 70 B. U. L. Rev. 731, 731 (1990).

41. Most features of contemporary American conflicts law are objects of vociferous and intractable debate by conflicts scholars, a chronic state of affairs examined at length in Shreve, supra n. 15, at 85-152, and summarized in Shreve, "Notes From the Eye of the Storm," 48 Mercer L. Rev. 823 (1997). "There is now in our conflicts literature such an disparate, often contradictory, accretion of policies, rules, systems, catchphrases, diagnoses, and proposed cures that it seems almost impossible for theorists now writing to demonstrate with complete success how their ideas are new, helpful, or even intelligible." Id. at 828. 
troubled or difficult) approach the subject with compassion and solidarity. "We know of no matter in jurisprudence so unsettled, or none that should more teach men distrust for their own opinions, and charity for those of others." 42

\section{An Interdisciplinary Turn}

With Saul as its laboratory, the Essay has made some progress in isolating, defining, and giving value to altruistic judicial argument. We have separated argument entirely disconnected from the court's decision from argument defending that decision directly or indirectly. Everything in the judicial opinion is argument in the public interest. It follows that disconnected material in the opinion speaks to the public interest in a more general, undifferentiated sense. That is, all such material is at least an attempt at altruistic argument. Moreover, the attractive features of Saul suggest intuitively that the case illustrates not merely the attempt but the realization of altruistic argument.

But, because we still lack a theory of value for altruistic argument, it is difficult either to articulate what is good or desirable in Saul, or differentiate more generally good from bad attempts at altruistic argument. Without a theory of value-a normative instrument to illuminate and justify the purpose of altruistic argument-we cannot make further headway in understanding the phenomenon. And,

42. 5 Mart. at 589. The court's approach is in line with two contemporary attempts to account for both mind and feeling in choice of law. The first is by Professor Arthur T. von Mehren.

Those who work in the field of choice of law are, at times, discouraged by the apparently intractable nature of the problems with which they must grapple. Intricate and subtle analyses are undertaken; ambiguities and uncertainties are painfully resolved. Ultimately, a result is reached, yet the solution is too frequently neither entirely satisfying nor fully convincing.

The process of analyzing and deciding fully domestic cases is, of course, on occasion also difficult and the results reached are at times unsatisfying. Yet, overall, one is ordinarily less dissatisfied than with multistate cases. The deeper and more pervasive malaise engendered by these latter flows only partly from the relatively greater complexity of the analysis typically required; even where wholly domestic cases present a comparable order of difficulty, the solutions given in multistate cases are more likely to trouble one's sense of justice.

von Mehren, "Choice of Law and the Problem of Justice," 41 Law and Contemp. Probs. 27,27 (1977). The second is by the author.

Conflicts law is far from perfect. However, particular flaws have less to do with its unpopularity than one might think. Rather, it is the innate difficulties of analysis that have made conflicts controversial and have kept it that way. It may be a sad fact of human nature that the difficulty of a legal question is demonstrated less by agreement on that score among judges and commentators than by the rising decibel level of arguments over who is obviously right and obviously wrong. The prevailing approach to resolving conflictswhatever that approach then happens to be-will always be under attack.

Shreve, supra n. 12, at 911-12. 
to search for a theory of value for altruistic argument, we must alter our approach.

We have used thus far a lawyer-like mode of investigation. ${ }^{43}$ Yet it is revealing to note that our progress has actually been unaided by the law's own rules or arrangements. The law in fact takes no notice of altruistic argument as such. Arguments to the contrary do not withstand close examination.

To argue, for example, that law has provided the category of dictum for altruistic argument, merely illustrates the maxim: "what the legal system cannot answer it organizes." 44 For dictum is conventionally understood in the law to be precisely what altruistic argument is not-justification of the court's decision (albeit in diluted form). ${ }^{45}$ It is similarly unsound to suggest that the law's negative valuation of dictum ${ }^{46}$ is a valuation of altruistic argument. The latter probably shares some of the faults of conventional dictum ${ }^{47}$ but not others. ${ }^{48}$ Most important, there is no evaluation in holding/dictum distinction or elsewhere in the law of the selfless and civic impulse reflected in altruistic judicial argument.

Saul appears to be proof that altruistic argument is capable of occurring unrecognized. Since altruistic judicial argument does occur, however, it would be particularly helpful if our legal discipline spoke to the phenomenon. And if our initial sense is that there may be something beneficial about altruistic argument, perhaps the legal community should consider recognizing and encouraging it. ${ }^{49}$ That

43. Our critique of altruistic argument has progressed by applications of logic and common sense in line with the "special fascination" here "among lawyers and judges with their own behavior, their own processes of thought." Freund, "An Analysis of Judicial Reasoning," appearing in Law and Philosophy 282 (Sidney Hook, ed. 1964).

44. Thomas L. Shaffer \& Robert S. Redmount, Lawyers, Law Students and People 7 (1977).

45. See supra $n$. 30 and accompanying text.

46. E.g., Judicial Opinion Writing Manual 14 (American Bar Association 1991) ("dictum is rarely of value"); George, supra n. 32, at 143 ("dicta. . .should be avoided").

47. Like conventional dicta, altruistic arguments add to the length of judicial opinions, and excessive length is a concern. E.g., Ruggero J. Aldisert, Opinion Writing 271-75 (1990); Federal Judicial Center, Judicial Writing Manual 23 (1991); Beardsley, "Judicial Draftsmanship," 24 Wash. L. Rev. 146 (1949). And because altruistic arguments (like conventional dicta) are not part of the holding, the authority for American courts to make them is less secure. See supra n. 31 .

48. Recall that, unlike altruistic argument, conventional dictum is a roundabout way of rearguing the correctness of the court's decision. Because it is so near the holding in form and function, conventional dictum suffers by comparison. It is thought to be wasteful per se, vague in its untethered pronouncements of law, and at times confusingly like the holding in appearance. See Comment, "Dictum Revisited," 2 Stan. L. Rev. 509 (1952); Sarnoff v. American Homes Products Corp., 798 F.2d 1075, 1084 (1986) (per Posner, J.).

Cf. Wald, supra n. 30, at 1410 ("one judge's dicta may be another judge's coherent rationale" for the decision).

49. What form that might take is not, for present purposes, very important. It might simply be a change in the attitude and judicial practice that makes the rule and policies of the current holding \dictum distinction important. 
could be done. After a period of assimilation, altruistic argument would be as naturally a part of our legal tradition as the holding $\backslash$ dictum distinction that it would modify.

The problem is that full evaluation of the law reform issue, whether to rework the holding \dictum distinction to create a discrete place for altruistic argument, is impossible if limited to the precincts of law as an autonomous discipline. ${ }^{50}$ Referring only to itself, law would not find in its rules, habits, and attitudes justification for this change. In other words, there is nothing within the law from which to construct a theory of value for altruistic argument. And, with no means of demonstrating its desirability, altruistic argument could never gain recognition in the law.

So we have two related problems. First, we are stalled in the process of isolating and defining altruistic argument. Saul invites thought about the reality and desirability of altruistic argument, but we need a theory of value for altruistic argument to continue our investigation. We cannot develop such a theory without concrete normative help from some quarter, and the law offers none. Second, contemplation of altruistic argument is more useful if we can at least imagine the possibility of its recognition in the law. But the law offers nothing to justify such a reform. Again, we feel the lack of a theory of value.

If we confine our investigation to the discipline of law, we may have reached a dead end. But material that would permit a theory of value for altruistic argument (and consequently support a case for law reform) may exist outside the law-within the systems, proofs and defining traditions of a nonlegal discipline. Can we find help elsewhere? Let us see by consulting the traditions of rhetoric and pragmatism. ${ }^{51}$

50. The viability of this concept is now a matter of debate. In his famous defense of law as an autonomous discipline, Professor Charles Fried concludes:

The law's rationality is a rationality apart. Is that a scandal? Why? We can

teach it and students can learn it. We can recognize better and worse examples of it. When we say of a judge or lawyer that he is learned in the law, we assume that there is a body of knowledge to be learned in, and that such learning increases wisdom, judgment, and justice.

Fried, "The Artificial Reason of the Law or: What Lawyers Know," 60 Texas L. Rev. 35, 58 (1981). For the opposing view, see Posner, "The Decline of Law as an Autonomous Discipline: 1962-1987," 100 Harv. L. Rev. 761 (1987).

51. The Essay for convenience refers to pragmatism as a discipline, although it might be more accurate to refer to it as a school or subdiscipline of philosophy.

While time and page constraints make it difficult to discuss even these two nonlegal disciplines, investigation under more than two would actually be helpful. For example, perspectives on reading literature would bear on the way in which the Essay interprets the passages from Saul presented in Part II. Examples from the law and literature movement include Theodore Ziolkowski, The Mirror of Justice-Literary Reflections of Legal Crises (1997); Martha C. Nussbaum, Poetic Justice-The Literary Imagination and Public Life (1995); Interpreting Law and Literature-a Hermeneutic Reader (Sanford Levinson \& Steven Mailloux, eds. 1988); James B. White, The Legal Imagination-Studies in the Nature of Legal Thought and Expression (1973). Simi- 


\section{Rhetoric, Pragmatism, and the Value of Altruistic Judicial Argument}

\section{A. Uses of Rhetoric and Pragmatism in This Essay}

\section{(1) Rhetoric}

An ancient topic, the meaning of "rhetoric" has changed over time.52 "But whatever the particular definition, the term has been applied to the use of language (or of special kinds of language) for the moving, pleasing, or persuading of readers or auditors to specific judgments, decisions, or actions." 53 Rhetoric, writes Thomas Farrell, "is the collaborative art of addressing and guiding decision and judgment-usually public judgment about matters that cannot be decided by force or expertise." Farrell explains that for society rhetoric "is an institutional formation in which motives of competing parties are intelligible, audiences available, expressions reciprocal, norms translatable, and silences noticeable." 54

From the beginnings of rhetoric as a discipline, its affinity with law has been clear. ${ }^{55}$ Explaining the matter in contemporary terms, Professor H.L.A. Hart stated:

larly, the Essay would probably benefit from a historical perspective on Saul and on the life and times of Judge Potter. On the nature and potential of historiography in legal criticism, see Symposium, "The Critical Use of History," 49 Stan. L. Rev. 1021 (1997); G. Edward White, Intervention and Detachment-Essays in Legal History and Jurisprudence (1994).

52. Since the time of Greek antiquity, the definition of "rhetoric" has changed from century to century as the idea of "rhetoric" has been expanded to cover the whole of the art, or contracted to include only a part. Generally, idea and definition-responding to the political or intellectual uses to which the art was put-have moved from considerations of language to the arguments or the passions expressed by language, to the effects produced by rhetorical compositions, to the relationships between such compositions and abstract concepts ("truth" or "justice"); then back to language.

Weinberg, "Rhetoric After Plato," appearing in Dictionary of the History of Ideas (Philip P. Weiner, ed., vol. IV 167 1973).

53. Id. See generally George A. Kennedy, A New History of Classical Rhetoric (1994) (Greek and Roman foundations of rhetoric); Thomas M. Conley, Rhetoric in the European Tradition (1990) (receptions of rhetoric in Europe); and American Rhetoric: Context and Criticism (Thomas W. Benson, ed. 1989) (receptions of rhetoric in the United States).

The growing importance of rhetoric here has been described as follows.

Renewed interest in rhetoric has surfaced in a wide range of conferences and publications across several academic disciplines. $* * *$ Besides the rapid growth of such rhetorically oriented fields as Composition Studies, several other disciplines have been significantly affected by the "rhetorical turn" in the humanities and social sciences, for example, philosophy, law, literary theory, cultural studies, anthropology, sociology, political science, speech communication, and even economics.

Mailloux, "Sophistry and Rhetorical Pragmatism," appearing in Rhetoric, Sophistry, Pragmatism 1 (Steven Mailloux, ed. 1995).

54. Thomas B. Farrell, Norms of Rhetorical Culture 1 (1993).

55. In the fifth century Greece, private property litigation in Syracuse inspired the first system of rhetoric, rhetoric grew in importance in Athenian courts, and scenes approximating legal argument were frequently used as rhetorical devices in 
The connection between law and the study of argumentrhetoric in the old non-pejorative sense of that wordis. . .clear. Legal reasoning characteristically depends on precedent and analogy, and makes an appeal less to universal logical principles than to certain basic assumptions peculiar to the lawyer; it therefore offers the clearest and perhaps most instructive example of modes of persuasion which are rational and yet not in the logical sense conclusive. ${ }^{56}$

Commentators have reached a variety of conclusions about the application and value of rhetoric to legal theory. ${ }^{57}$ Much of the recent legal literature, however, shares Farrell's emphasis on the social importance of rhetoric. The trend has been termed "communitarian revivalism." 58 It is in this sense that rhetoric is important to the essay.

\section{(2) Pragmatism}

Pragmatism emerged before the beginning of this century as an American philosophical movement, ${ }^{59}$ and "[i]t is primarily as a move-

Greek literature. Kennedy, supra n. 53, at 11-16. "Republican Rome shared the Greek interest in debate and legal argument, and therefore considered rhetoric essential to public life." McArthur, "Rhetoric," appearing in the Oxford Companion to the English Language 865 (Tom McArthur, ed. 1992).

56. Hart, "Introduction," appearing in Ch. Perelman, The Idea of Justice and the Problem of Argument vii (1963).

57. See, e.g., Posner, "Judges Writing Styles (And Do They Matter?), 62 U. Chi. L. Rev. 1421 (1996); The Rhetoric of Law (Austin Sarat \& Thomas R. Kearns, eds. 1994); Wald, supra n. 30; Richard H. Gaskins, Burdens of Proof in Modern Discourse (1992); Wetlaufer, supra n. 24; James Boyd White, Heracles'Bow-Essays on the Rhetoric and Poetics of the Law (1985). A valuable survey of the uses of rhetoric in legal literature appears in Sarat \& Kearns, id. at 1-27.

58. Goodrich, "Antirrhesis: Polemical Structures of Common Law Thought," appearing in Sarat \& Kearns, supra n. 58, at 59. Goodrich, while not an adherent of this movement, describes it thus:

[Rhetoric's] practical value to the study of law is almost universally perceived

to be resident in its capacity to produce agreement. $* * *$ Rhetoric will return

language to nature, eloquence to the institution, and community to law.

Rhetoric will not only save law from the specter of nihilistic indeterminancies

of interpretation but will equally return the art of judgment to its proper

ethical parameters as a genre of civil speech.

Id. at 57-58.

59. Leading figures in the development of pragmatism included Charles Sanders Peirce, William James, John Dewey, C.I. Lewis, and George Herbert Mead. Studies of individual philosophers and their work include John $\mathrm{K}$. Sheriff, Charles Peirce's Guess at the Riddle (1994); Joseph Brent, Charles Sanders Peirce-a Life (1993); Peirce, Semeiotic, and Pragmatism-Essays by Max H. Fisch (Kenneth Laine Ketner \& Christian J.W. Kloesel, eds. 1986); W. B. Gallie, Peirce and Pragmatism (1966); Gerald E. Myers, Williams James-His Life and Thought (1986); Ralph Barton Perry, In the Spirit of William James (1938); Ralph Barton Perry, The Thought and Character of William James (2 vols., 1935); James Campbell, Understanding John Dewey (1995); Robert B. Westbrook, John Dewey and American Democracy (1991); The Philosophy of John Dewey (Paul Arthur Schlipp \& Lewis Edwin Hahn, eds., 3d ed. 1989); R.W. Sleeper, The Necessity of Pragmatism-John Dewey's Conception of Philosophy (1986); Morton White, The Origins of Dewey's Instrumentalsim (1943); Sidney Hook, John Dewey-An Intellectual Portrait (1939); "C.I. Lewis Commemorative Sympo- 
ment rather than by any one doctrine that pragmatism is best understood."60 The philosophical community never arrived at a settled definition of "pragmatism." 61 Nor have legal scholars been able to agree what they mean when they appropriate pragmatism. ${ }^{62}$ Nor have scholars been able to agree whether or how pragmatism in legal theory differs from philosophical pragmatism. ${ }^{63}$ Yet it is possible to

sium," 61 J. Phil. 545 (1964); Hans Joas, G.H. Mead-A Contemporary Re-examination of His Thought (1985).

General accounts of pragmatism as a philosophical movement include Paul K. Conklin, Puritans \& Pragmatists 193-402 (1968); Elizabeth Flower \& Murray G. Murphy, A History of Philosophy in America, Vol. II 567-692, 811-958, 965-72 (1977); Bruce Kuklick, The Rise of American Philosophy 104-26, 159-79, 533-62; H.S. Thayer, Meaning in Action: a Genealogy of Pragmatism (1989); Morton White, Pragmatism and the American Mind (1973); Philip P. Weiner, Evolution and the Founders or Pragmatism (1949).

American pragmatists never claimed to have originated the ideas and system of pragmatist thought. William James actually entitled one of his books Pragmatism-A New Name for Some Old Ways of Thinking (1907). Features of pragmatism were anticipated, for example, in teachings of the Greek sophists (Frederick Copleston, A History of Philosophy, Book One 95 (1985)) and in Aristotle's concept of practical wisdom (E.S. Hutchinson, "Ethics," appearing in the Cambridge Companion to Aristotle 207 (Jonathan Barnes, ed. 1995)).

60. Thayer, "Introduction," appearing in Pragmatism: The Classic Writings 11 (H. S. Thayer, ed. 1970).

61. A pragmatist recently observed: "I do not think of pragmatism as a set of doctrines or even as a method." Richard J. Bernstein, The New Constellation: the EthicalPolitical Horizons of Modernity/Postmodernity 324 (1993). In the same vein, Philip P. Weiner noted a 1908 study by Arthur O. Lovejoy that identified thirteen different (and to an extent conflicting) meanings of pragmatism. Lovejoy's study, explained Weiner,

raised the problem of whether there was any coherent core of ideas that could define the doctrine or movement that was so widely discussed by American and European thinkers in various disciplines. Certainly Charles S. Peirce and William James (who credited Peirce in 1897 with inventing the doctrine) had divergent ideas in their "pragmatic" theories of truth. There were also divergences among those writers in the United States and abroad who defended their own particular versions of pragmatism.

Weiner, "Pragmatism," appearing in Dictionary of the History of Ideas, vol. III 551 (Philip P. Weiner, ed. 1973).

62. Over the past twenty years, legal scholars have frequently discussed applications of philosophical pragmatism in legal theory. E.g., Baker, "Just Do It': Pragmatism and Progressive Social Change," 78 Va. L. Rev. 697 (1992); Grey, "Holmes and Legal Pragmatism," 41 Stan. L. Rev. 787 (1989); Patterson, "Law's Pragmatism: Law as Practice and Narrative," 76 Va. L. Rev. 937 (1990); Posner, supra n. 4, at 454-69; Smith, "The Pursuit of Pragmatism," 100 Yale L. J. 409 (1990); Stick, "Can Nihilism Be Pragmatic?," 100 Harv. L. Rev. 332 (1986); Summers, "Pragmatic Instrumentalism in Twentieth Century American Legal Thought-A Synthesis and Critique of Our Dominant General Theory About Law and Its Use," 66 Cornell L. Rev. 861 (1981);

For examples of the converse, pragmatist philosophers writing about law, see Dewey, "Logical Method and Law," 10 Cornell L. Q. 17 (1927); Rorty, "The Banality of Pragmatism and the Poetry of Justice," 63 S. Cal. L. Rev. 1811 (1990); Putnam, "Are Moral Values Made or Discovered?," 1 Legal Theory 5 (1995).

63. For recent attempts to differentiate the two, see Posner, "Pragmatic Adjudication," 18 Cardozo L. Rev. 1 (1996); Grey, "Freestanding Legal Pragmatism," 18 Cardozo L. Rev. 21 (1996); Rosenfeld, "Pragmatism, Pluralism, and Legal Interpretation: Posner's and Rorty's Justice Without Metaphysics Meets Hate Speech," 18 Cardozo L. Rev. 97, 103-10 (1996). 
come up with a brief, twofold understanding of pragmatism that will serve this Essay.

First, the core:

The characteristic idea of philosophical pragmatism is that efficacy in practical application-the issue of 'which works out most effectively'-somehow provides a standard for the determination of truth in the case of statements, rightness in the case of actions, and value in the case of appraisals. ${ }^{64}$

Many embellishments to this core definition of pragmatism might be possible. ${ }^{65}$ One, pragmatism's mediating and healing properties, provides the second and concluding part of the Essay's understanding of the term. I have previously offered the idea of mediation in suggesting how pragmatism can be a powerful instrument for understanding and improving law. I argued that pragmatism can function at the far reaches of discourse about the meaning and value of law, to clarify and mediate forces of nonpragmatist thought. My thesis was that, while pragmatism in legal theory can be far more than a commonplace reminder to be sensible, pragmatism by its terms is not a competitive legal theory. It is thus unlike natural law, positivism or historical jurisprudence. Pragmatism may be as important as these grand theories, but (in a way unique to pragmatism) it is important only because of other theories. This is a communitarian, pluralistic role for pragmatism. Pragmatism is a citizen, so to speak, with a mission to test, clarify, and mediate impulses generated elsewhere within a larger community of ideas. ${ }^{66}$

64. Rescher, "Pragmatism," appearing in the Oxford Companion to Philosophy 710 (Ted Honderich, ed. 1995). It is possible to describe pragmatism in legal theory at about the same level of generality:

First, it conceives the primary task of legal theory to be the provision of a coherent body of ideas about law which will made law more valuable in the hands of officials. . . .Second [it takes the view] that legal rules and other forms of law are most essentially tools devised to serve practical ends. . . Third, [it focuses] on the instrumental facets of legal phenomena, including: the nature, variety, and complexity of the goals the law may serve; law's implementive machinery; the kinds of means-goal relationships in the law; the variety of legal tasks that officials must fulfill to translate law into practice, the efficacy of law; and its limits.

Robert S. Summers, Instrumentalism and American Legal Theory 20 (1982).

65. Various refinements of and additions to the basic idea of pragmatism represented in the text appear in three collections. "Symposium: The Revival of Pragmatism," 18 Cardozo L. Rev. 1 (1996); Pragmatism in Law \& Society, (Michael Brint \& William Weaver, eds. 1991); "Symposium on the Renaissance of Pragmatism in American Legal Thought," 63 S. Cal. L. Rev. 1569 (1990).

66. Shreve, "Symmetries of Access in Civil Rights Litigation: Politics, Pragmatism and Will," 66 Ind. L. J. 1, 31-37, 50-52 (1990). Cf. Grey, supra n. 63, at 37-38 ("pragmatists argue that the grand theories, if understood as partial perspectives, do not cancel each other out, but rather that each of them has something to contribute to the understanding of law."). 
This rendering of pragmatism is compatible with the general approach of contemporary pragmatists (neopragmatists ${ }^{67}$ ). Sandra Rosenthal's recent construction of pragmatism provides an example. ${ }^{68}$ At the same time, the capacity of pragmatism to clarify and mediate the clash of ideas was first and fully explained by John Dewey. And it is upon Dewey's approach that I shall chiefly rely.

\section{B. Can Rhetoric and Pragmatism Help Us Develop a Theory of Value for Altruistic Argument?}

\section{(1) Rhetorical and Pragmatist Readings of Saul}

We must remember that to call Judge Potter's work altruistic argument is to make two representations. The first is that he attempted altruistic argument. The second is that the attempt was successful. We have already noted why all statements in a judicial opinion wholly unrelated to the decision are at least attempts at altruistic argument. The contributions of rhetoric and pragmatism will be to sharpen the distinction between good and bad attempts.

The affinity between rhetoric and pragmatism has been noted ${ }^{69}$ and will become evident later when the two perspectives converge in this Essay. Let us begin, however, by noting how each contributes separately to our understanding of altruistic argument in Saul. Recall the gist of that argument. Conflicts law is a subject that merits

67. While their predecessors distrusted propositions that could not be verified pragmatically, neopragmatists incline toward pluralism. This shift is due in large part to the tendency of first-generation pragmatists to exaggerate scientific method's capacity to clarify matters of rational belief and justification. Neopragmatists are wary of scientific method and attempt more diffuse applications of pragmatism.

Shreve, supra n. 66 , at 29 (citations omitted).

Today's neopragmatists include Richard Rorty, Hillary Putnam, and Richard Bernstein. See, e.g., Richard Rorty, Consequences of Pragmatism (1982); Hilary Putnam, Pragmatism (1995); Richard J. Bernstein, Philosophical Profiles-Essays in a Pragmatic Mode (1986); Richard J. Bernstein, The New Constellation (1992).

68. Sandra B. Rosenthal, Speculative Pragmatism (1986). Professor Rosenthal undertakes a "speculative synthesis" of the doctrines advanced by Peirce, James, Dewey, Lewis, and Mead. Id. at 3. In a passage close in spirit to the second idea of pragmatism offered in the text, Rosenthal explains how her conception of speculative pragmatism meets an important challenge to philosophy.

[I]t must offer not just a system based on the evidence it sees, but it must account for the fact that the different philosophies differ as to what constitutes the nature of evidence. It must offer not just a theory of truth, but it must account for the fact that different philosophies differ as to what constitutes the nature of truth. It must offer not just foundations, but it must account for the fact that different philosophies differ concerning the very foundations of philosophy. It must be not just another system in conflict, but it must account for the fact that there can be systems in conflict.

Id. at 197 (emphasis added).

69. Mailloux, "Introduction," appearing in Rhetoric, Sophistry, Pragmatism 1-3 (Steven Mailloux, ed. 1995); John Patrick Diggins, The Promise of Pragmatism-Modernism and the Crisis of Knowledge and Authority 3 (1994); Thomas M. Conley, Rhetoric in the European Tradition 7 (1990); Perelman, supra n. 56. 
our serious attention, even when it does not yield satisfactory answers in application. We must therefore leaven our hard work on conflicts with patience and respect for the work of others.

What distracted Judge Potter from the customary practice of self-justification and caused him to argue for the sake of conflicts law and all in society affected by it? I believe he was practicing what James Boyd White has called "constitutive rhetoric," that is, "the central art by which culture and community are established, maintained, and transformed."70 We deal with notions that are also important elsewhere. The influence of the concept of community in legal theory extends beyond law and rhetoric scholarship. ${ }^{71}$ And rhetoric's applications to the law extend beyond the judicial argument. ${ }^{72}$ But the rhetorical concept, argument for the sake of community, seems particularly vivid in Saul. It stands out in Judge Potter's personal investment, imagination, and compassion for the lawyers and judges who are law's actors and for the society law affects..$^{73}$

In part then the communitarian rhetoric of Saul's message suggests its place as altruistic argument. To illustrate, assume that Judge Potter chose instead to ridicule choice of law and those who take it seriously. ${ }^{74}$ This too would have been an attempt at altruistic argument because it would have been argument off the subject of decision, to a larger audience, and about more general legal concerns. However, it would be a failed attempt. ${ }^{75}$ It would instead be bad rhetoric, ridicule of the efforts of others to make something out of con-

70. White, supra n. 57, at 28.

71. See, e.g., "Symposium: Law and Civil Society," 72 Ind. L. J. 335 (1997). One of the contributors described the position of the "modern communitarian movement" as "arguing that certain communities so deeply shape their members that they are constitutive of their identities." Williams, "A Feminist Reassessment of Civil Society," 72 Ind. L. J. 417, 419 (1997). Additional studies of communitarianism include Daniel Bell, Communitarianism and its Critics (1993); Universalism vs. Communitarianism (David Rasmussen, ed. 1990).

72. See supra n. 58 and accompanying text.

73. Various statements of this ideal appear in White, "What is an Opinion For?," 62 U. Chi. L. Rev. 1363, 1367-69 (1995); Nussbaum, "Poets as Judges: Judicial Rhetoric and the Literary Imagination," 62 U. Chi. L. Rev. 1477, 1482, 1519 (1995). This is not to suggest that communitarianism can be embraced uncritically. For example, Professor Susan Williams writes, "the endorsement of existing communal forms and institutions-including the patriarchal family-is unacceptable to feminists who have been struggling to reveal the oppressive nature of such institutions." Supra n. 70, at 422-23. Anyone proposing a communitarian approach to law, as I do in this Essay, must acknowledge that the "community" must become more accommodating. See generally, Ethnicity and Group Rights (Ian Shapiro \& Will Kymlika, eds., Nomos XXXIX, 1997); and the sources appearing under the heading, "outsider scholarship," in supra n. 4.

74. For examples this behavior in conflicts opinions, see supra n. 39 .

75. An opinion may be authoritarian or democratic, generous or mean spirited, doctrinaire or open to multiple arguments, and so on-indeed, it may exhibit many of the ethical and political qualities that other kinds of conduct can.

White, supra n. 73 , at 1367 . 
flicts law-an example of what one commentator has labeled "the rhetoric of reaction."76

By definition, "altruistic" argument would "be actuated by the well-being of others."77 Inclusive, empathic and collaborative, altruism is a powerful idea in fields like science ${ }^{78}$ and education. ${ }^{79}$ The rendering of altruism by communitarian rhetoric provides the first half of our theory of value for altruistic judicial argument. For a useful formulation, we turn again to Professor White:

If an opinion is narrow minded or unperceptive or dishonest or authoritarian, it will trivialize the experience of those it talks about, and it will trivialize the law too. If it is open and generous, full of excitement at the importance it gives to the events and the people it speaks of, and to its own treatment of them as well, it will dignify the experience of those it talks of, in so doing it will dignify the law itself. It may even be touched by nobility. ${ }^{80}$

Pragmatism is also humanitarian in purpose, but in a more roundabout way than communitarian rhetoric. The latter ministers directly to human needs; pragmatism does so indirectly through the improvement of knowledge. Pragmatism is "geared to inquiring after the possibilities of science and of democracy and to finding a meaningful life for the individual." 81 Pragmatism's contribution to our understanding of altruistic argument comes from its tolerant, inquisitive way of perceiving the clash of ideas, ${ }^{82}$ its skepticism about the intractability of problems, ${ }^{83}$ its energetic search for solutions

76. Albert O. Hirschman, The Rhetoric of Reaction (1991). The author discusses practices of "criticizing, assaulting, and ridiculing" to develop theses of "perversity," "futility" and "jeopardy". Id. at 7.

77. The Compact Edition of the Oxford English Dictionary Vol. 1, p. 65 (1971).

78. John A. Schumacher, Human Posture-The Nature of Human Inquiry 15 (1989).

79. Robert Coles, The Moral Intelligence of Children (1997).

80. White, supra n. 73 , at 1368 . White is not directing his discussion, as we are, to judicial argument disconnected from decision. Yet his means of differentiating good from bad judicial argument in general applies equally well in sorting good from bad attempts at altruistic argument.

81. Hans Joas, Pragmatism and Social Theory 1 (1993).

82. This picture extends to the beginning of pragmatism. Despite their fondness for empiricism and scientific method, first-generation pragmatists directed their energies into the world of ideas. And they did so without the foundational, reductive biases of their predecessors.

[T] hey avoided replacing metaphysical assumptions with new certainties based on some philosophy of history, or theory of Reason, and did not regard the end of these certainties as a cause for desperation. $* * *$ As they saw it, neither science nor democracy had ceased to have validity simply because it no longer seemed possible to provide any final justifications for them.

Boas, id. at 1.

83. The spirit of pragmatism is to welcome the challenge of problems, to formulate and resolve problems in a way most helpful to society. This is best represented in Dewey's own instrumental description of problems and problem solving. 
through observation and experience. ${ }^{84}$ Communitarian rhetoric promotes harmony and growth within communities of people. Pragmatism seeks the same for communities of ideas. ${ }^{85}$ Both contribute to the healing and mediating properties of altruistic judicial argument.

The pragmatism of Judge Potter's argument is evident in his refusal either to disparage conflicts law or to choose sides on the doubtful premise that one school of thought is or could possibly be superior to all others. Judge Potter's attitude toward the elaborate, contending conflicts theories of his time was characteristic of pragmatists, who "argue that the grand theories, if understood as partial perspectives, do not cancel each other out, but rather that each of them has something to contribute to the understanding of law."86

It marks Saul's pragmatism that, by example and by exhortation, Judge Potter expressed the need for an open mind about a very difficult legal subject. Many judges and far too many conflicts commentators have been less pragmatic. The judges in this category tend to be hostile to theory. ${ }^{87}$ Commentators tend to embrace a single complex conflicts theory to the exclusion of all others. ${ }^{88}$ Theory

We compare life to a traveler faring forth. We may consider him first at a moment where his activity is confident, straightforward, organized. He marches on giving no direct attention to his path, nor thinking of his destination. Abruptly he is pulled up, arrested. Something is going wrong in his activity. From the standpoint of an onlooker, he has met an obstacle which must be overcome before his behavior can be unified into a successful ongoing. From his own standpoint, there is shock, confusion, perturbation, uncertainty. For the moment he doesn't know what hit him. . .nor where he is going. But a new impulse is stirred which becomes the starting point of an investigation, a looking into things, a trying to see them, to find out what is going on. Habits which were interfered with begin to get a new direction as they cluster about the impulse to look and see. The blocked habits of locomotion give him a sense of where he waS going, of what he had set out to do, and of the ground already traversed. As he looks, he sees definite things which are not just things at large but which are related to his course of action. The momentum of the activity entered upon persists as a sense of direction, of aim; it is an anticipatory project. In short, he recollects, observes and plans.

John Dewey, Human Nature and Conduct 181-82 (Modern Library ed. 1930) (emphasis in original). For discussions of Dewey's instrumentalism and its central place in pragmatism, see Campbell, supra n. 59, at 13-22; Parodi, "Knowledge and Action in Dewey's Philosophy," appearing in The Philosophy of John Dewey 229-42 (Paul Arthur Schlipp \& Lewis Edwin Hahn, eds., 3rd ed. 1989); Thayer, supra n. 59, at 169-74; White, The Origin of Dewey's Instrumentalism, supra n. 59.

84. In pragmatism, human beings, their purposes, and their actions occupy the central position in the universe. The very word "pragmatism" signifies an act, deed or affair. It can hardly be surprising, then, that when this philosophy became prominent in America, legal theorists came to see law more as an instrument for human use than as an abstract object for disinterested analysis and study.

Summers, supra $\mathrm{n} .64$, at 31 .

85. See supra n. 66 and accompanying text.

86. Grey, supra n. 63 , at $37-38$.

87. For examples, see the judges quoted in supra $n .39$.

88. [S]cholars have written massive articles attempting to reconceptualize the subject. These exercises in conflicts metatheory are erudite and highly 
can be exasperating, ${ }^{89}$ and it takes a special kind of inquisitiveness and stamina to keep an open mind on complex theoretical matters in the law. Pragmatism in altruistic argument provides direction, stimulus, and human support ${ }^{90}$ for such an undertaking.

There is a concord in altruistic argument between the humanism of communitarian rhetoric and pragmatist attentiveness to a community of ideas. Argument best suited to the ends of each proceeds in a tone of patience and civility. And, like communitarian rhetoric, pragmatism values human community. ${ }^{91}$ The two conceptions of community are sufficiently close that by straining we probably could have used either rhetoric or pragmatism alone to fill out our complete picture of altruistic argument. But it is helpful that both apply, for each places half of the picture in full perspective.

ambitious. But they are also abstruse, contentious, and virtually impossible to convert into practice or to assimilate into a more catholic understanding of conflicts theory.

Shreve, Notes From the Eye of the Storm, supra n. 41, at 828 . The tactful but trenchant reaction of a pragmatist to this state of affairs might be to muse: "so often we think the problem 'solved' when our abstraction has so overcome our opponent's that, for the moment, he can think of no other abstraction with which to counter-attack." Geiger, "Dewey's Social and Political Philosophy," appearing in The Philosophy of John Dewey, supra n. 59, at 345-46.

89. Theory wields a double intimidation; on the one hand it suggests the pertinence of a vast range of things you don't know, but if you attempt to catch up, put a lot of work into reading and the things people tell you should know, you discover that theory is not settled knowledge that you can comfortably apply. Theory is not a field you could ever master, though it simultaneously presents mastery as a goal (you hope that theoretical reading will give you the concepts, the metalanguage, to order and understand the phenomena that concern you) and makes mastery impossible, not just because there is always more to know, but more specifically and more painfully because theory is itself the questioning of presumed results and the assumptions on which they are based. The nature of theory, by this account, is to undo, through a contesting of premises and postulates, what you thought you knew, so that there may appear to be no real accumulation of knowledge or expertise.

Culler, "Introduction: What's the Point?" appearing in The Point of Theory-Practices of Cultural Analysis 14-15 (Mieke Bal \& Inge E. Boer, eds. 1994).

90. A compassionate force has long been evident in pragmatism. Dewey's concern about the conditions of life for others in society has been well-documented. E.g., James Livingston, Pragmatism and the Political Economy of the Cultural Revolution 188-89 (1994); Cornel West, The American Evasion of Philosophy-A Genealogy of Pragmatism 80-81 (1989); Jurgen Habermas, Toward a Rational Society 68-69 (1970); Richard Hofstadler, The Age of Reform 154 (1955); Campbell, supra n. 59, at 144-51; Westbrook, supra n. 59, passim; Hook, supra n. 59, at 226-39. William James exhibited that concern. Hilary Putnam, Pragmatism 23 (1995); Perry, supra n. 59, at 122; Myers, supra n. 59, at 424. So did G.H. Mead; Joas, supra n. 59, at 21-26.

91. Pragmatism took exception to the stark individualism of formal, classic liberalism and stressed the cooperative nature of human endeavor. It image of reason was not the endless calculation of self-interest but the collaborative contrivance of workable methods of action.

Charles W. Anderson, Pragmatic Liberalism 1 (1990). Cf. Putnam, "A Reconsideration of Deweyan Democracy," 63 S. Cal. L. Rev. 1671, 1674 (1990) (describing “Dewey's justification" as "a social justification-that is, one addressed to the community as a whole rather than to each member of the community"). 
What help have uses of rhetoric and pragmatism turned out to be to our investigation? They have verified our intuition that Saul represents altruistic argument. But what have rhetoric and pragmatism contributed to a general distinction between good and bad attemptsto isolation, definition, and valuation of altruistic judicial argument? Here is what we can say. Judicial argument that is entirely indifferent to the correctness of the ruling does not, by that alone, succeed as altruistic argument. On the other hand, it would be wrong to say that particular arguments are truly altruistic only if we agree with them. Altruistic argument must reflect some high civic impulse, whether solicitude for law, or for those it affects, or for those in the legal community required to use it. Rhetoric and pragmatism help to articulate these features in altruistic argument.

(2) Double Checking the Contributions of Rhetoric and Pragmatism: the Banality/Relativism Question

Resistance to the conception of altruistic argument is to be expected within the legal community. ${ }^{92}$ However, there is a different kind of resistance that must be noted. The precepts of rhetoric and pragmatism upon which my idea of altruistic argument depends are familiar to practitioners of those disciplines, but they are also controverted. By entering in a small way the interdisciplinary discourse about the contemporary value of rhetoric and pragmatism, this Essay becomes open to criticisms found in that discourse. Unfortunately, space remains only to discuss the most persistent of these criticisms: attacks of banality and relativism.

The charge of banality can be made against rhetoric, ${ }^{93}$ but surfaces more often today against pragmatism. Usages of pragmatism in legal writing merely to underscore the value of practicality or common sense ${ }^{94}$ do not draw such criticism. It is only when (as in this

92. Conservatism runs deep in our judiciary. Even one of most enlightened jurists wrote: "There is something monstrous in commands couched in invented and unfamiliar language; an alien master is the worst of all. The language of the law must not be foreign to the ears of those who are to obey it." Hand, "Is There a Common Will?, 28 Mich. L. Rev. 46, 52 (1929).

93. See Bernard S. Jackson, Making Sense in Law-Linguistic, Psychological and Semiotic Perspectives 62 (1995) (noting the challenge that "rhetoric. . .becomes any successful communication."). Cf. Mcarthur, supra n. 55, at 866 ("As the 19c progressed, the ancient theorists became of less and less interest, except to classical scholars, and rhetoric became for many either the (empty) forms of public speaking or the study of writing and composition in schools."); Vayne, "The Roman Empire," appearing in A History of Private Life 20, 23 (Paul Vayne, ed. \& Arthur Goldhammer, trans. 1987) ("in Rome the minds of little boys were decked out with rhetoric, much as in the last century the bodies of little boys were decked out with sailor suits or military uniforms. $* * *$ There was a gulf between true eloquence and rhetorical teaching, which the ancients never ceased to deplore even as they delighted in it.").

94. In popular usage, pragmatism connotes purposeful conduct, a preference for weighing the effects of possible actions and choosing the most practical course. Pragmatism's commonly accepted role in legal discourse is much the 
Essay) a greater, more freestanding role is assigned to pragmatism that accusations of banality arise. ${ }^{95}$ Charges of relativism ${ }^{96}$ made against rhetoric ${ }^{97}$ and (more frequently) against pragmatism represent the same attack from a different direction. If the two are banal, they can be used to dress up any point of view. Thus, J.M. Balkin offered as a reason for becoming a legal pragmatist: "You can also be (a) a civil republican, (b) a feminist, (c) a deconstructionist, (d) a casecruncher, (e) a crit, (f) a law-and-economics type, or (g) anything else."98

The brunt of the banality $\backslash$ relativism attack has been directed at a supposed frailty in pragmatism, sometimes called the "fact/value dichotomy."99 This is the problem.

Pragmatism, particularly the Deweyan side most influential today, is designed around the process of finding and solving problems. But what are the problems? How, when and why do we define them? Pragmatism is often thought to eschew moral (substantive) values, but it must have a moral base somewhere to escape relativism. That is, pragmatism can neither call something a problem nor value one solution to it over another without substantive reference points. Hence the dilemma. If pragmatism is substantive, does it

same: a kind of ad hoc exhortation that we keep an eye on the reliability of our methods and the success of our results.

Shreve, supra n. 66 , at $26-27$ (citations omitted).

95. "[I]f legal pragmatism is only eclectic, result-oriented, historically minded antiformalism, it turns out to be a remarkably uncontroversial doctrine. It stands free of philosophical controversy only because it stands free of all controversy, and it avoids controversy by saying very little." Luban, "What's Pragmatic About Legal Pragmatism?" 18 Cardozo L. Rev. 43, 45 (1996) (emphasis in original). Cf. Balkin, "The Top Ten Reasons to Be a Legal Pragmatist," 8 Constitutional Commentary 351, 351 (1991) ("Being a legal pragmatist means never having to say you have a theory."); Rorty, "The Banality of Pragmatism and the Poetry of Justice," 63 S. Cal. L. Rev. $1811,1813(1990)$ ("Pragmatism was reasonably shocking seventy years ago, but in the ensuing decades it has gradually been absorbed into American common sense."); Albert Schinz, Anti-Pragmatism 286 (1909) ("Common sense, left to itself, settles nothing.").

96. Relativism has been defined as holding "that there are no universal truths about the world: the world has no intrinsic characteristics, there are just different ways of interpreting it." Pojman, "Relativism," appearing in the Cambridge Dictionary of Philosophy 690 (1995); as the "permanently tempting doctrine that in some areas at least, truth itself is relative to the standpoint of the judging Subject." Simon Blackburn, Oxford Dictionary of Philosophy 326 (1994).

In philosophical writing, relativism is not always a disparaging term. See, e.g., Richard Rorty's sympathetic conception of relativism in Philosophy and the Mirror of Nature 373-79 (1979).

97. One of the definitions of rhetoric accepted for "more than 2000 years" is: "An insincere eloquence intended to win points and get people what they want." McArthur, supra n. 55 , at 863 .

98. Balkin, supra n. 95, at 351. See also Minow \& Spellman, "In Context," 65 S. Cal. L. Rev. 1597 (1990); Singer, "Should Lawyers Care About Philosophy?" 1989 Duke L.J. 1752, 1754-55; Schrag, supra n. 7, at 171.

99. Putnam, supra n. 62 , at 12 . 
contradict itself? If pragmatism lacks substantive reference, is it not hopelessly relativistic? ${ }^{100}$

In keeping with the views of Hillary Putnam, ${ }^{101}$ Richard Bernstein, ${ }^{102}$ Thomas Grey, ${ }^{103}$ and Robert Summers, ${ }^{104}$ the "community of ideas" concept of this Essay seeks a way out of the dilemma. Pragmatism can have a distinctive resonance and a place within a community of grand theories without itself becoming one more competing theory. Michael Moore is wrong in maintaining the contrary, that "[d]ifferent types of legal theory must genuinely compete with each other about the nature of some aspect of the law."105

For example, if solutions for a legal problem posed from the value systems of natural law, positivism, and historical jurisprudence conflict, ${ }^{106}$ Dewey's instrumental pragmatism could function separately not to provide a fourth contending solution but to clarify and mediate debate among the other three. ${ }^{107}$ As Putnam explained:

[N]o distinction is more insistent in Dewey's writing than the distinction between the valued and the VALUABLE. Dewey's answer to the question, "What makes something valuable as opposed merely to being valued? is, in a word, criticism. Objective value arises, not from a special "sense organ," but from the criticism of our valuations. Valuations are incessant and inseparable from all of our activities. . ., but it is by intelligent reflection on our valuations, intelligent reflection of the kind that Dewey calls "criticism," that we conclude that some of them are warranted while others are unwarranted."108

\section{CONCLUSION}

My purpose has been to examine the hitherto neglected phenomenon of altruistic judicial argument, and to do so in a way that gives readers a sense of the current jurisprudential climate in the United States. In the process, the Essay has undertaken a series of overlap-

100. Shreve, supra n. 66, at 34-35.

101. Putnam, supra n. 91; 1682-83; Putnam, supra n. 62, at 13-16; Putnam, supra n. 90 , at 57 .

102. Bernstein, supra n. 67 , at $260-72$.

103. Supra n. 86 and accompanying text.

104. Summers, supra n. 64 , at $20-22$.

105. Moore, "The Need for a Theory of Legal Theories: Assessing Pragmatic Instrumentalism," 69 Cornell L. Rev. 988, 1012 (1984).

106. On tensions between these three kinds of jurisprudence, see Berman, supra $\mathrm{n}$. 4.

107. See supra n. 66 and accompanying text.

108. Putnam, supra n. 62, at 13. Pragmatism is therefore both humble and sublime. It is "a philosophy rooted in common sense and dedicated to the transformation of culture, to the resolution of the conflicts that divide us." Sleeper, supra n. 59, at 89. 
ping projects. The first was to isolate, define and evaluate altruistic judicial argument. The second was to demonstrate how the interdisciplinary turn in legal criticism can evolve naturally out of traditional legal inquiry. The third was to propose an alloy of rhetoric and pragmatism to extend the idea of community both to persons and to ideas.

The problems raised in this Essay would profit from a longer study. This is especially true concerning the interdisciplinary discussion in PART IV. Insofar as I have merely applied ideas about rhetoric and pragmatism from existing paradigms, the contribution possible for the Essay would be, to paraphrase Thomas Kuhn's comment on the natural sciences,

an actualization achieved by extending the knowledge of those facts that the paradigm displays as particularly revealing, by increasing the extent of the match between those facts and the paradigm's predictions, and by further articulation of the paradigm itself. ${ }^{109}$

If, however, the communitarian synthesis of rhetoric and pragmatism offered in this Essay represents something beyond any established paradigm, and if it has aided investigation of altruistic judicial argument, it may be useful in many other settings as well.

109. Thomas S. Kuhn, The Structure of Scientific Revolutions 24 (3d ed. 1996). As Kuhn notes, the effect of a paradigm in sweeping away prior, divergent approaches probably has no counterpart outside the sciences. id. at 17. Rather, legal criticism presents the opportunity for simultaneous development of many paradigms.

Kuhn's powerful, paradigm-based imagery nonetheless helps to set apart the important functions of application and innovation when we think of rhetoric and pragmatism as legal theory. 
